\title{
The specificity of the Scythian panoply of the Lower Danube
}

\section{Denis Topal}

\begin{abstract}
The archaeological landscape of the Lower Danube was changing with the importance of the Danube itself, which either became, or a cultural watershed, or an artery, connecting the ancient communities. In the Early Iron Age, it seems that the Danube did not become an invincible barrier for the spread of offensive weapons of Scythian origin. Moreover, Dobruja itself looks like a territory mastered by the Scythians, starting from the Archaic period. The Lower Danube group forms a separate "steppe" cultural assemblage together with the Lower Dniester, South Carpathian and South Danube groups, for which the spear became the main type of weapon. However, these preferences were reflected in the morphology of the Scythian akinakes. So, for this steppe or Danube enclave, swords are more characteristic than daggers. Daggers are connected mainly with the forest-steppe part of the Carpathian-Dniester region and Transylvania. The warrior graves of the Lower Danube region mainly belong to the Classical Scythian period, while the only exception is related to the right bank of the Lower Danube. However, there are no burials with akinakai and even stray finds in Classical time outside the steppe. The main funeral practice is the burial mound and inhumation (one exception of cremation was recorded to the west, in northeastern Bulgaria, near Branichevo). In Late Classical time (350 - 300 BC) the Scythian akinakes also evolves in the steppe: an original series of single-edged akinakai of the Chaush type appear; besides that, Thracian combat knives are borrowed. Then the Scythian akinakes dissolves with the disappearance of the Classical Scythian culture at the turn of 4th-3rd centuries BC. Something similar happens a century earlier in the forest-steppe between the Dniester and Siret rivers. The complete disappearance of akinakes dates back there in the late 5th century BC. Thus, in the Scythian time, the Lower Danube becomes kind of frontier, or the territory, where cultures meet, clash, and grapple with each other, often in contexts of highly asymmetrical relations of power.
\end{abstract}

Keywords: Scythian; Early Iron Age; Lower Danube; weapons; panoply; the akinakes; the spearheads; axes; swords; daggers.

The archaeological landscape of the Lower Danube was changing with the importance of the Danube itself, which either became, or a cultural watershed, or an artery, connecting the ancient communities. In the Early Iron Age, it seems that the Danube did not become an invincible barrier for the spread of offensive weapons of Scythian origin. Moreover, Dobruja itself looks like a territory mastered by the Scythians, starting from the Early Scythian period. After all, since 


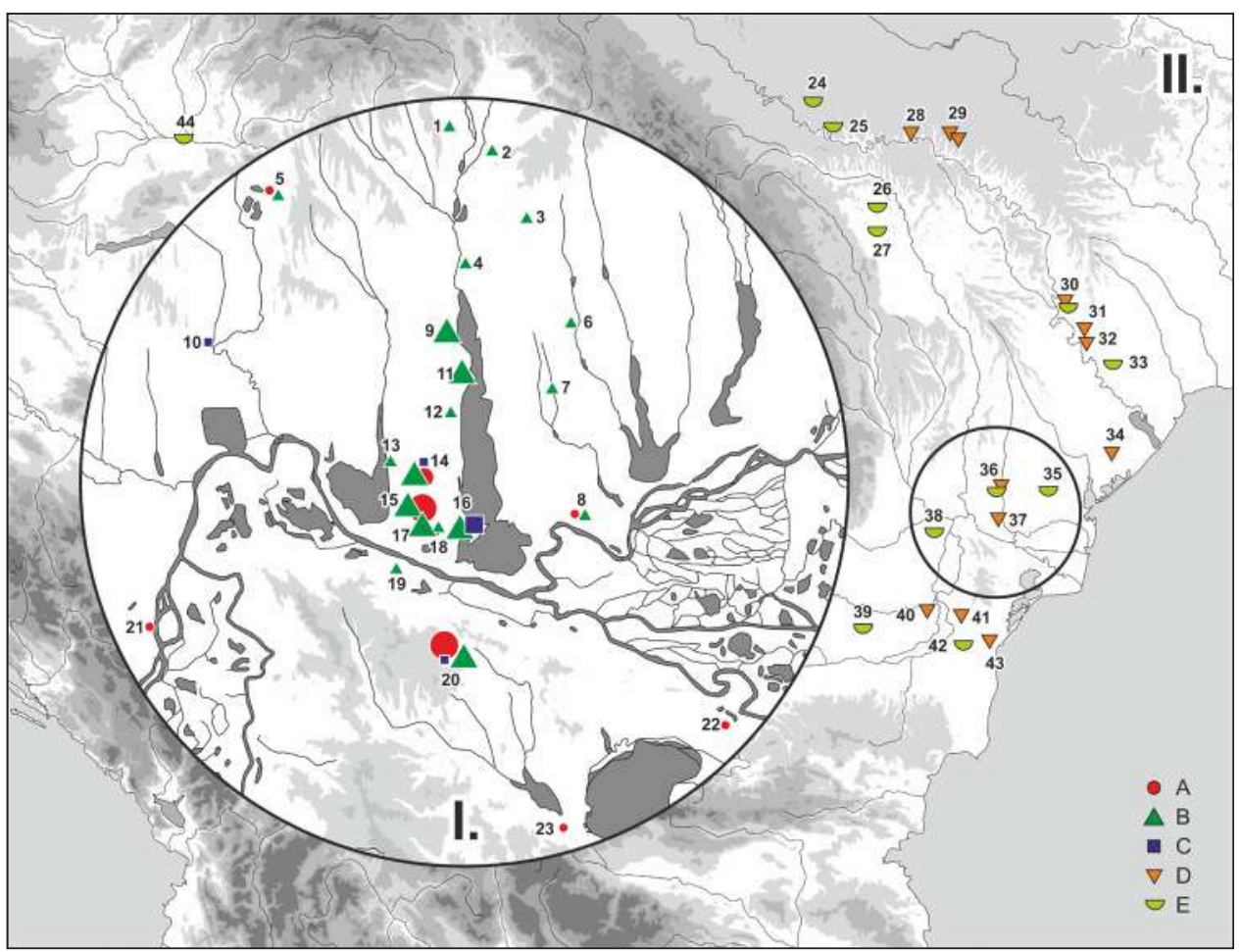

Fig. 1. Scythian period in Carpathian-Danube region. I. Swords and daggers (A), spearheads and javelins (B), axes (C): 1 - Balabanu, 2 - Taraclia, 3 - Kubey, 4 - Tabaki, 5 - Crihana Veche, 6 - Vasilyevka, 7 - Kalanchak, 8 - Izmail, 9 - Mresnota Mogyla, 10 - Șivița, 11 - Vladycheni, 12 - Kotlovina, 13 - Nagornoe, 14 - Plavni, 15 - Chaush, 16 - Kugurluy, 17 - Gradeshka, 18 - Dervent, 19 - Isaccea, 20 - Celic-Dere, 21 - Chiscani, 22 - Murighiol, 23 - Enisala. II. Statues (D) and bronze cauldrons (E): 24 - Shvaykivtsy, 25 - Ivane-Puste, 26 - Avrămeni, 27 - lacobeni-Dângeni, 28 - Loevtsy, 29 - Nizshiy Olchedaev, Kukavka, 30 - Dubossary, 31 - Butor, 32 - Krasnogorka, 33 - Nikolskoe, 34 - Yaroslavka, 35 - Ostrovnoe, 36 - Vinogradovka, Mresnota Mogyla, 37 - Plavni, 38 - Scorțaru Vechi, 39 - Ograda, 40 - Platonești, 41 - Stupina, 42 - Castelu, 43 - Sibioara, 44 - Szőny.

the $6^{\text {th }}$ century BC on the Medgidia Plateau (between Constanța and Cernavoda in Romania), very characteristic materials appear, which are hard to explain only by influences or intercultural contacts (Fig. 1, II; Fig. 2). It has long been known of three Scythian anthropomorphic statues: from Sibioara (Fig. 2, 1), Stupina (Fig. 2, 3) and the find from Dobrudja (Fig. 2, 6) (Alexandrescu 1958, fig. 1, 2, 4; 1960, 384, fig. 1; Vulpe 1990, Taf. 18: 96, 97). Besides, not far from Medgidia, a unique bronze cast model or an emblem of a Scythian akinakes was found, possibly also made to decorate the statue (Berciu 1959, 18, fig. 1, a, c, pl. 3). Closely to them is the find of the bronze cauldron from Castelu (Fig. 2, 10) (Aricescu 1965, 565-570, fig. 1; Sîrbu 2015, 55, fig. 4) discovered also near Med- 


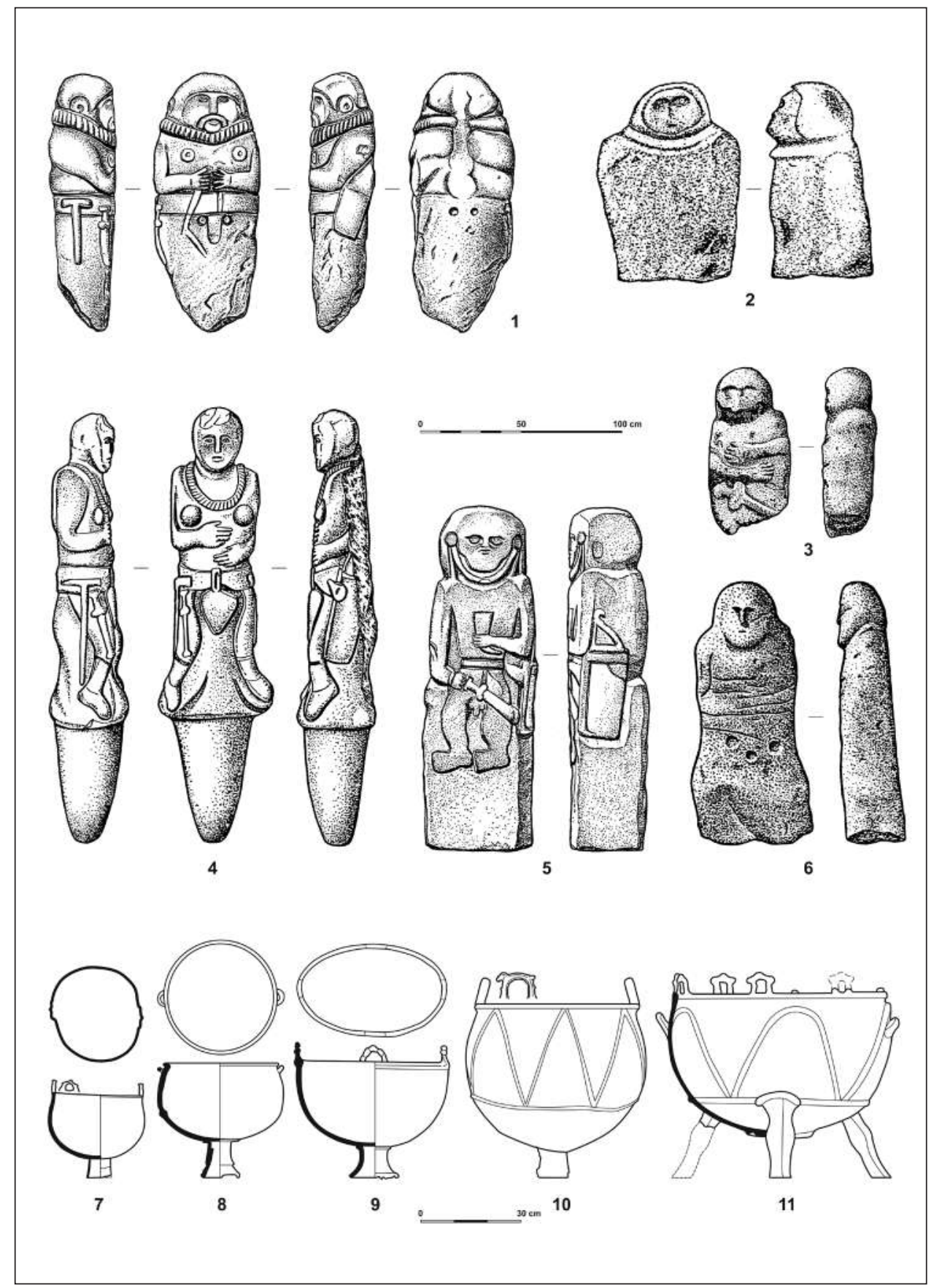

Fig. 2. Scythian stone statues (1-6) and bronze cauldrons (7-11) from the Lower Danube: 1 - Sibioara, 2 - Platonești, 3 - Stupina, 4 - Vinogradovka, 5 - Plavni, 6 - Dobruja passim, 7 - Ograda, 8 - Mresnota Mogyla, 9 - Ostrovnoe, 10 - Castelu, 11 - Scorțaru Vechi. 

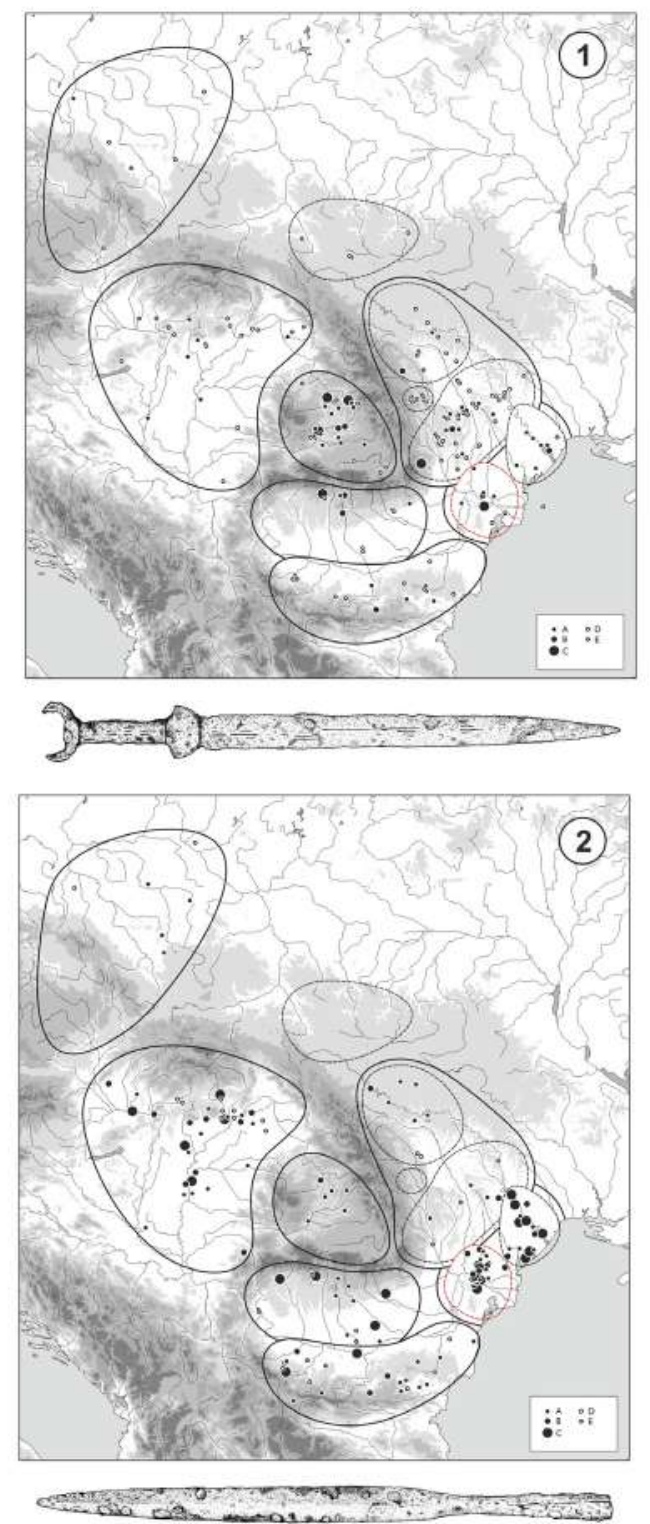
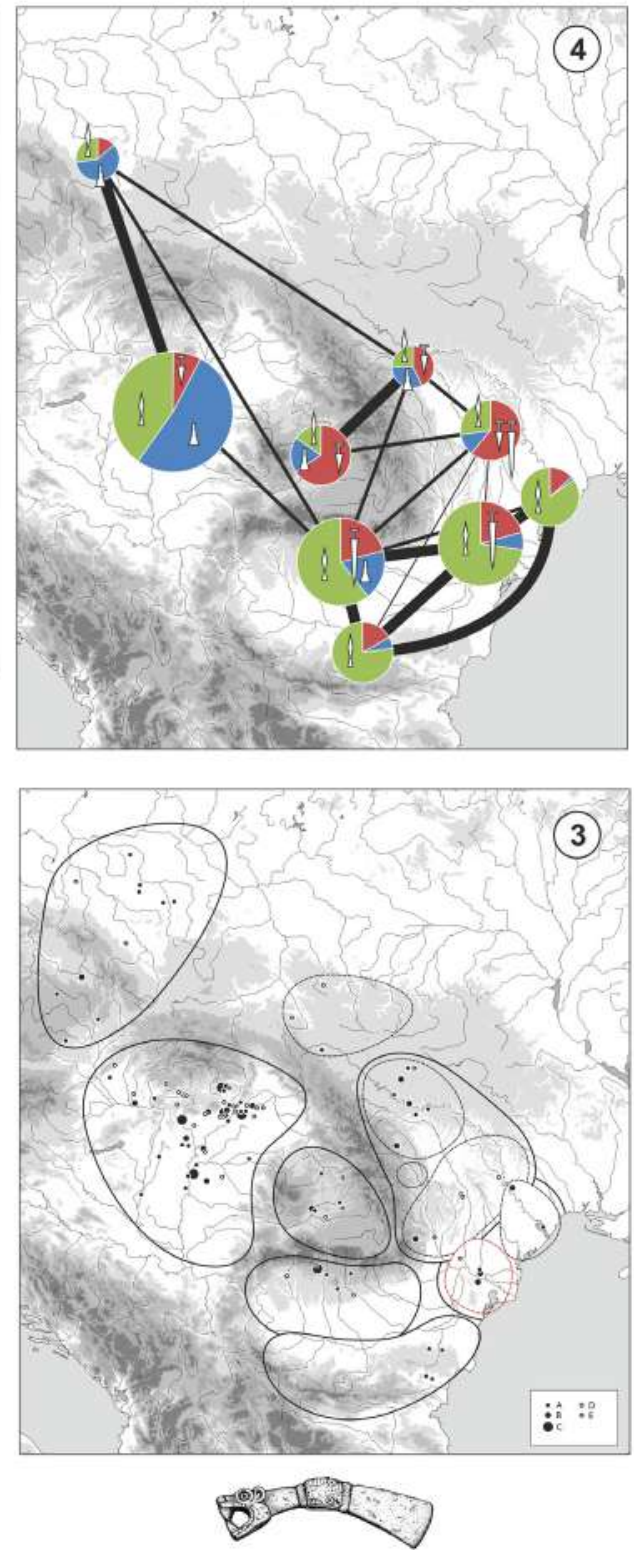

Fig. 3. Distribution of swords (1), spearheads (2) and axes (3) in the Carpathian-Danube region and the correlation between the local cultural groups (4). Burials: A - 1 ex.; B - 2-3 ex.; C - more than 3 ex.; D - stray finds; E - destroyed burial.

gidia. The Scythian penetration to the Baragan steppe is probably shown by the statue from Platonești (Fig. 2, 2) (Matei, Coman 2000, fig. 1a) and the cauldrons from Ograda (Fig. 2, 7) and Scorțaru Vechi (Fig. 2, 11) (Sîrbu 2015, 54-55, fig. 2, 
3; Pârvan 1926, 9-11, fig. 1). These are the most western finds of Scythian cauldrons in Europe, after a bronze cauldron found on the Hungarian-Slovak border near Szőny (Patay 1990, 81, Taf. 68: 148). The correlation between the finds of Scythian statues and bronze cauldrons is quite stable, their main clusters, as a rule, coincide, for instance, on the Dniester and Western Podolia - Bukovina. And on the contrary, in the zone between Carpathians and Dniester (on the territory of the so-called Moldavian group), where we observe a lot of assemblages and artefacts of Scythian origin (including weapons), neither Scythian statues nor Scythian cauldrons are found (Fig. 1, II).

Interestingly, the repertoire of Scythian statues of the Lower Danube differs from the panoply in the same territory. On the statues, in descending order are akinakai, bows and axes (Fig. 2, 1, 3-5). At the same time, it is well known that in the North-Western Black Sea region the spearheads are the most popular and basic weapons for the Scythian panoply (Ostroverkhov, Redina 2013, 393) and this doesn't differ this region from its nearest neighbours. Judging by the panoply, the Lower Danube organically fits into the so-called Danube or steppe cultural enclave, which also includes the Lower Dniester region, the South Carpathian region and the Southern Danube (Topal 2018, 175). This cultural enclave is characterized by a predominance of spearheads, long swords with a minimum of axes (Fig. 3). The other two enclaves are distinguished, in one case, by the predominance of axes (western enclave consisting of Great Hungarian Plain and Silesia), in the other case by daggers and medium swords (the Carpathian enclave, consisting of Transylvania, Moldova and Western Podolia) (Topal 2018, 187).

The spearheads are the most common find of weaponry in Scythian burials of the Northwest Black Sea region, after arrowheads, of course (Ostroverkhov, Redina 2013: 393). The spearheads from such assemblages of the left bank of Lower Danube were introduced into the scientific circuit: e.g. barrow 27 (Fig. 4, 11, 12, 22) (Andrukh, Dobrolyubsky, Toshchev 1985, 66, fig. 26, 5-7) and 32 (Fig. 4, 21) of Plavni-I burial ground. The fragments also come from burial 1 of barrow 2 and burial 1 of barrow 26 (Sunichuk, Fokeev 1984, fig. 2, 5, 15), the burial of 1 barrow 8 (Fig. 4, 15) and burial 6 of barrow 5 (Fig. 4, 16, 17) of Gradeshka burial ground; burial 1 of barrow 5 at s. Vladychen (Fig. 4, 18) (Ostroverkhov, Redina 2013, 389, fig. 92, 7-13), barrow 12 of the Chaush burial ground (Sunichuk 1985, 41, fig. 15), burial 4 of barrow 4 of Gradeshka-I burial ground, burial 2 of barrow 1 (Fig. 4, 13) of Tabaki burial ground, burial 1 of barrow 12 (Fig. 4, 19) of the Kubey burial ground, burial 5 of barrow 3 near Vasilyevka (Subbotin et al. 1992, fig. 2, 7; 4: 8; 8: 3). At the same time, spearheads from the burial grounds of Kotlovina-I, Kalanchak, Dervent, Kugurluy, Ostrovnoye remain still unpublished. 


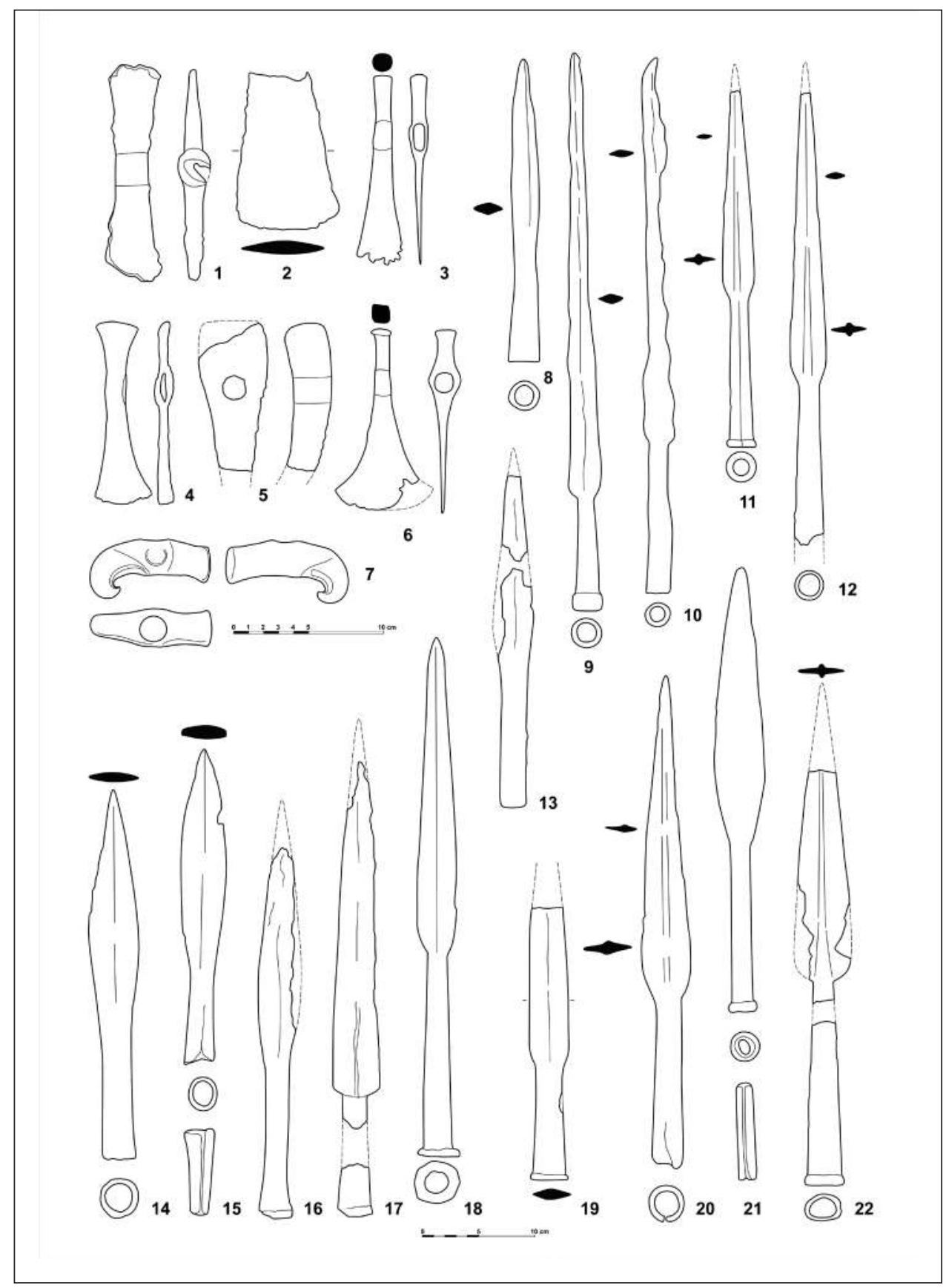

Fig. 4. Selected axes (1-7) and spearheads (8-22) of Scythian period from the Lower Danube: 1, 2 - Kugurluy (1 - b.11, gr. 1; 2 - b.29, gr. 1); 3, 6-10 - Celic-Dere (7 - b. 11 a); 4 - Șivița; 5, 11, 12, 20-22 - Plavni-I (5 - b.32; 11, 12, 22 - b. 27; 20 - b. 28; 21 - b. 32); 13 - Tabaki b.1, gr. 1; 14 - Dervent b. 14, gr. 1; 15-17 - Gradeshka-I (15 - b. 8, gr. 1; 16, 17 - b.6, gr. 6); 18 - Vladychen b.5, gr. $1 ; 19$ - Kubey b. 12, gr. 1 . 
Despite the abundance of burials with spearheads, they date back to the time not earlier than the middle of the $5^{\text {th }}$ century BC. Though the looting in antiquity, the main burial of the barrow 3 of the "Mresnota Mogyla" burial ground contained besides the spearheads, the iron body armour and the shield (Redina $1992,84)$. This grave is well-dated back by black-glazed skyphos and partly by the amphorae (of unidentified centres), and is attributed to the third quarter of the $5^{\text {th }}$ century BC (Monakhov 1999, 139-140; Polin 2014, 203). A female burial with two spears in the barrow 6 near Balabanu (Chebotarenko, Yarovoy, Telnov 1989, 36, fig. 14, 1) also could be dated back to the last quarter of the $5^{\text {th }}$ century BC. (Teleaga 2008, 364). Besides the supposed spear in the burial 2 of barrow 3 at Ostrovnoe were found two pythoid Heraclean amphoras of I-4 variant (according to S. Yu. Monakhov) with the stamp of API $\Sigma$ TOK $\mid \Lambda H \Sigma$ $\operatorname{APT} \Omega N \mid \triangle \mathrm{A}$ and the one more hardly recognizable by Satyrion (?). That allows dating the complex to the late $5^{\text {th }}-$ early $4^{\text {th }}$ centuries BC or 395-390 BC (Monakhov 1999, 205-206; Kats 2007, 429; Polin 2014, 305). Judging by the funeral feast near the barrow 27 at Plavni, which contained two Thasian Early Biconic, one Heraclean and two amphorae of Murighiol type (Monakhov 1999, 181-182), this assemblage can be attributed to the early $4^{\text {th }}$ century BC. The stamp of APX $\mid \mathrm{E} \Lambda \mathrm{A}$ on the Heracleian amphora of type I allows dating the barrow 27 within the first decades of the $4^{\text {th }}$ century BC or within $410-390$ BC (Monakhov 1999, 182; Polin 2014, 304).

On the right bank of the Lower Danube, at least five spearheads (Fig. 4, 8-10) come from the burials of the Celic-Dere burial ground (Simion 2005, fig. 6, 3): e.g., from the 10-B burial (Simion 1992, 102, fig. 4; 1992a; fig. 5a). So far, one can only speculate about the chronological position of this burial (as well as many others excavated by G. Simion), but probably this grave should be attributed to the final phase of the burial ground, the lower boundary of which is the end of the $5^{\text {th }}$ century. BC. Thus, the most popular type of individual weaponry of the Scythians of the Lower Danube region relates mainly to the Classical Scythian period, and possibly, partly to the end of the Middle Scythian period.

Axes are known from the following burials on the left bank of the Danube: burial 1 of barrow 11 (Fig. 4, 1), burial 1 of barrow 29 (Fig. 4, 2) of Kugurluy burial ground (Ostroverkhov, Redina 2013, 391, fig. 93, 11, 13) and burial mound 32 (Fig. 4, 5) of Plavni-I burial ground (Sunichuk, Fokeev 1984, 114, fig. 4,16 ). It is difficult to judge the dating of these complexes in each case, but it is obvious that they belong to the Classical Scythian culture. Moreover, it is reasonable to place these burials from Kugurluy, following most of the dated graves (Polin 2014, 585), in the second half of the $4^{\text {th }}$ century BC, or even closer to the end of the century. 
On the right bank of Danube River, a two-blade axe, similar to an item from Kugurluy, was discovered near Shivița village (Fig. 4, 4) of Galați County (Dragomir 1983, 88, fig. 11, 4). In the Celic-Dere burial ground near the Telița village were found at least two single-bladed iron axes (Fig. 4, 3, 6) (Simion 2005, fig. 5, 2) and one bronze bird-headed sceptre (Fig. 4, 7) (Simion 2005, fig. 6,1$)$. The sceptre decorated in the animal style in the shape of a bird's head with a curved beak comes from the burial 11. This assemblage (according to G. Simion) refers to the final phase of the burial ground or the late $5^{\text {th }}$ - early $3^{\text {rd }}$ century BC (Simion 1992, 104). Most of the analogical scepters are represented by stray finds: e.g. from P.O. Burachkov collection (Yatsenko 1959, pl. III: 3) in the Lower Dnieper, Kunderevich collection (Illinska 1961, fig. 11, 5), Pastyrskoe (Drevnosti Pridneprovya 1907, tab. IV: 428) in the forest-steppe of the right bank of Dnieper River. Another Scythian bird-headed sceptre is displayed in the Museum of the History of Arms in Zaporizhzhia (Murzin, Shlayfer 2008, 49-50, fig. 6), however, it is not cast from bronze, but forged from iron. Despite this difference, this item stylistically fits into the group of similar scepters of the early Classical time, therefore the dating by the authors within the " $7^{\text {th }}$ - the first half of $6^{\text {th }}$ century BC" (Murzin, Shlayfer 2008,49 ) seems unreasonably underestimated. Relatively recently it became known about the discovery of a bronze sceptre from the Crimea, found near the Partizany village of the Kirov District (Skoryi, Zimovets 2014, 135). A similarly shaped bronze bird-headed axe is kept at the Dobrich Historical Museum (Torbatov 1998, 1012; History at Dobrudja 2011, 167, fig. 152) in North-East Bulgaria. The only assemblage with a bronze scepter-axe was excavated near Zaporizhzhia, in the barrow 25 of the Kichkass burial ground (Illinska 1961, 44, fig. 11, 7). In addition to the axe, "an iron spearhead, 7 bronze arrowheads, 2 bronze finials and a bronze plaque in the shape of a bird of prey" were found in the burial, and the grave itself dates back to the late $5^{\text {th }}$ century BC (Yatsenko 1959, 63).

Swords and daggers. The border between the steppe Danube and Carpathian cultural enclaves lies literally along the landscape border of the steppe and forest-steppe. Namely, along the western fringe of the Lower Dniester Plain, the northern edge of the South Moldavian Plain and the Tigeci Upland. To the west of the Prut River, this border most likely limits the Bârlad Plateau from the south. Therefore, if we focus on the Carpathian-Dniester region, we will be able to detect many important trends in the weaponry. First of all, the trends are easy to trace with the help of swords and daggers or akinakai. The situation could be described by a basic metaphor from the books by George Martin. In the Scythian time, the Carpathian-Dniester region is characterized by such an abundance of akinakai that this period can be called the "storm of 


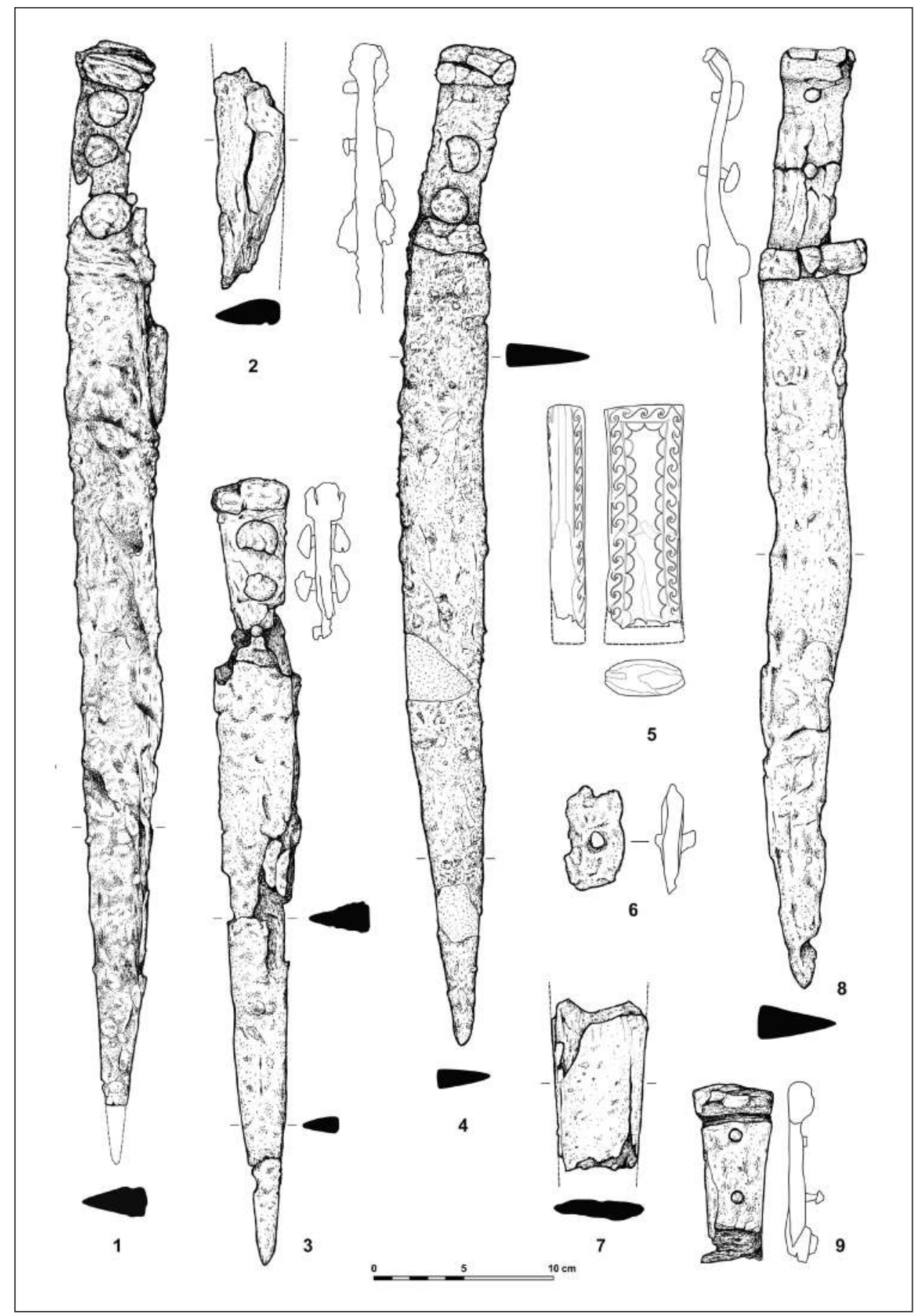

Fig. 5. Selected swords of the Late Classical period from the Lower Danube: 1, 2, 8, 9 - Chaush $(1$ - b. 15, gr. $1 ; 2$ - b. 15, gr. $2 ; 8$ - b. 12, gr. $1 ; 9$ - b. 11 , gr. 1$) ; 3,6,7$ - Plavni-I (3 - b. 24, gr. 1; 6 - b. 22, gr. $1 ; 7$ - b. 15, gr. 1); 4,5 - Crihana Veche (4 - b. 5, gr. 1; 5 - b. 7, gr. 2). 
swords" (Topal 2019, 141). We do not know a similar storm either before or after the Scythian period, and the bladed weapons of Scythian origin in Carpathian-Dniester were more popular than in any other region to the west of the Dniester. The region is also specific in that some of the Scythian type swords and daggers are associated with the nomadic entourage, some are found in a context, different from the typical Scythian one. On the other hand, in the Late Classical time (from the mid. $4^{\text {th }}$ century BC), Scythian steppe assemblages itself became open to the different cultural influences, both direct import and the import of ideas, which led to the emergence of hybrid forms. But if we ignore cultural differences and present the entire volume of burials with Scythian-type bladed weapons as a unified mass of warrior burials, we will find some signs that have landscape and chronological significance.

Unlike the forest-steppe zone of the Dniester region, the overwhelming majority of the akinakai finds in the steppe part refer to the Classical Scythian culture. The burials with the akinakai of Classical period are basically few and they are mainly associated with the territory of the Lower Dniester and the Lower Danube groups. According to V. S. Sinika $(2007,18)$, the swords and daggers were inside only the 30 graves or 5,7\% of all the Scythian burials of the steppe between Dniester, Prut and Danube. The only one burial with an akinakes could be dated to the Early Scythian period: the grave of the $2^{\text {nd }}$ sector of the burial ground II of Celic-Dere near Telița, Tulcea County, Romania (Simion 1992, fig. 1). This grave was considered by A. I. Melyukova (2001, 22) as a simultaneous one to the Sabangia barrow and dated back to the second half - the late $7^{\text {th }}$ century BC. Later, two items with a semicircular hilt from the Celic-Dere burial ground can be attributed to the end of the Middle Scythian period (the first half of the $5^{\text {th }}$ century). The hilt of one of them is decorated with engraving in Scythian animal style, similar to the decoration of daggers from Petricani and Tudora-Palanca. The earliest burials with bladed weapons of the Classical period are still located in Dobrudja: e. g. barrows 10a and 11 (Simion 1992, fig. 3, 5), as well as the recently excavated barrow 44 (Sîrbu et al. 2013, 356) of the Celic-Dere burial ground near Telița ${ }^{1}$. The main burial of the barrow 10a was dated back by G. Simion $(1992,104)$ to the third quarter of the $5^{\text {th }}$ century BC by the "Thasian" amphora, later this amphora was defined as "Samian" and dated to the late $5^{\text {th }}$ century BC (Teleagă 2008, 49, fig. 192.1011; Sîrbu et al. 2013, 350), but it chronology could be more accurate. G. Simi-

${ }^{1}$ Among the materials of the Celic-Dere burial ground excavated by G. Simion, at least eight akinakai are known (Simion 2005, fig. 6, 4). At the same time, judging the grave goods of burials that include this type of weaponry is rather problematic, because only two of them (10a and 11) are reliably attributed. 
on attributed barrow 11 to the period of the third quarter of the $5^{\text {th }}$ century $\mathrm{BC}$, basing on three amphorae and a bronze axe-sceptre, however, due to the lack of illustrations and description of the amphora, this dating is still in doubt. Barrow 44 from Celic-Dere is dated back, according to the authors of the excavations, to the second half of the $5^{\text {th }}$ century (Sîrbu et al. 2013, 356). Although a quiver set consisting of arrowheads with internal sleeves (Sîrbu et al. 2013, fig. 10d) indicates an earlier date, the upper limit of which is likely to come in the mid. $-5^{\text {th }}$ century BC. The similar sword was occasionally discovered on the territory of the Murighiol burial ground. It was traditionally dated back to the late $4^{\text {th }}$ - early $3^{\text {rd }}$ century BC (Bujor 1958, fig. 8.1, Vulpe 1990, 67, Taf. 17.80), but due to the recent discovery from Celic-Dere, there were reasons for its earlier dating, i.e. to the finale of Middle Scythian time.

A sword with slots and an imitation of a winding on a hilt, an oval ornamented pommel was found in the destroyed barrow on the territory of Izmail city in Odessa Region. According to the Heraclean amphora's stamp, the barrow is dated back to the early 360s BC (Palamarchuk, Sinika 2014, 296). Such swords with slotted handles of so-called Chertomlyk type (Topal 2014) mainly refer to the earlier time, i.e. to the first half of the $4^{\text {th }}$ century $\mathrm{BC}$, however, tending to the beginning of the century. This is indicated by other archaic features, such as imitation of wire or rope winding on the handle and ornamentation of the upper part of the blade with longitudinal grooves. The burial with a sword, discovered in 1958 on a destroyed burial ground near Chiscani (Harțuche, Anastasiu 1976, 197-198, 209, cat. 400-405, 422) contained an amphora attributed by V. Sîrbu $(1982,101)$ to the time after the 340 s BC. Besides that, it is known another akinakes from the vicinity of Chiscani, apparently also referring to the Classical Scythian culture (Andrukh 1995, fig. 4.25, Măndescu 2010, pl. 85.22).

The Scythian burial grounds of the Lower Danube also provide a series of original single-edged swords of Chaush type (Fig. 5, 1, 3, 4, 6, 8, 9). Seven items come from the eponymous Chaush burial ground, but only three of them could be entirely reconstructed: from the grave 12 (Fig. 5, 8), 15 (Fig. 5, 1) and 22 (Sunichuk 1985, 44, pис. 2: 16, 17; Redina 1999, 223-226, fig. 1, 2, 3; 2 : 1-3). These burials were dated back by E. F. Redina to the third quarter of the $4^{\text {th }}$ century BC. A similar sword was found in the barrow 24 of Plavni I burial ground (Fig. 5, 3). In general, the cemetery is considered to be simultaneous to Chaush and is also dated to the mid.-third quarter of the $4^{\text {th }}$ century BC (Sunichuk, Fokeev 1984, 117; Redina 1999, 223). The most recent find of Chaush type sword was revealed in Crihana Veche burial ground (Fig. 5, 4), in grave 1 of barrow 5 (Ciobanu, Simalcsik 2017, 23), but remains still unpublished. And it could be only supposed that this funeral complex is dated back to the second 


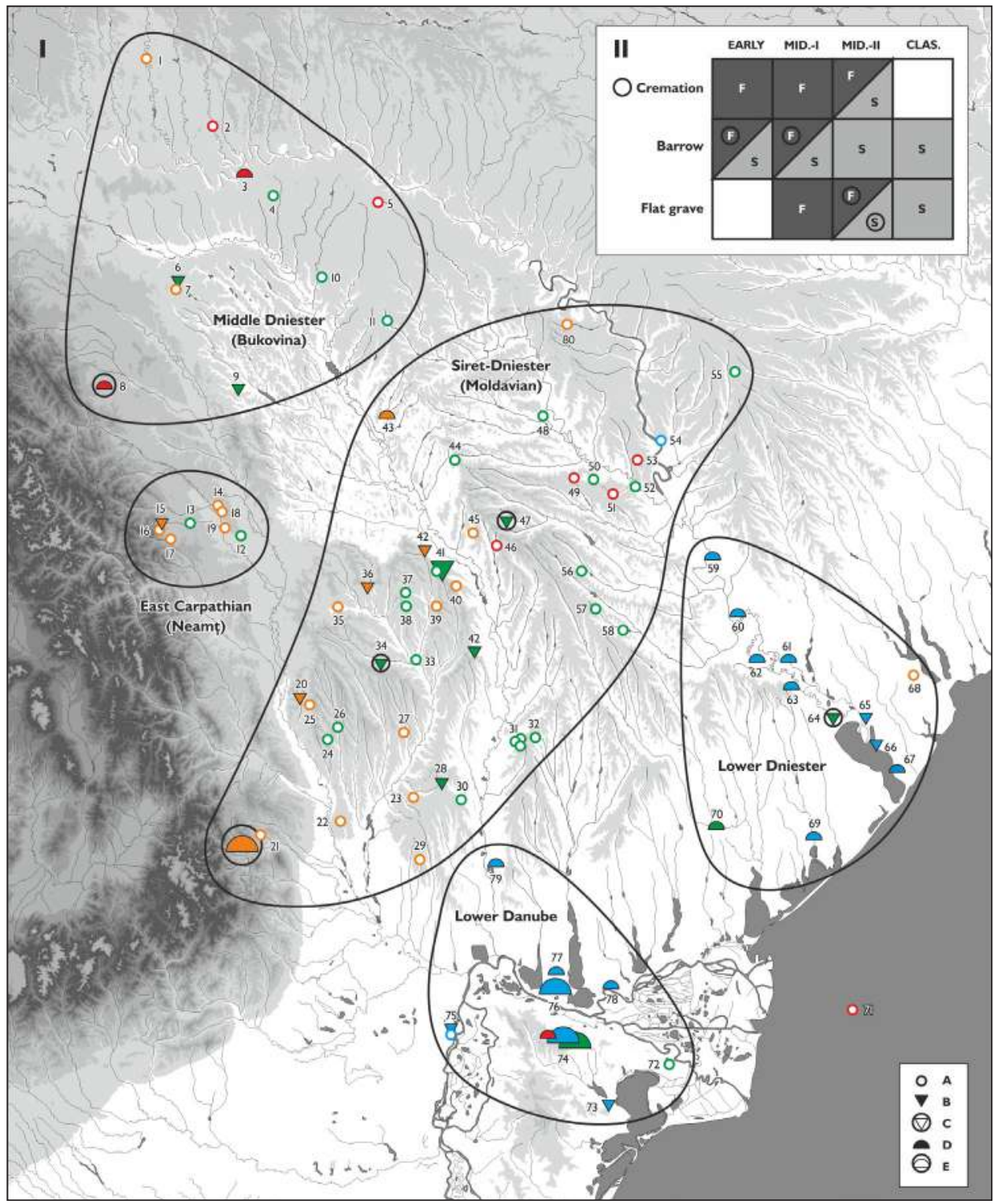

half of the $4^{\text {th }}$ century BC as other Scythian graves from Crihana Veche. But the Chaush type swords are distinguished (for example, from the Thracian combat knives) by the presence of an essential detail - the lower part of the handle, in contact with the blade, is equipped with a hilt. This made it possible to use such a sword not only for the chopping blows, characteristic of single-edged weapons but also for the stabbing ones.

The Thracian types of weapons became very popular in the Classical Scythian period, and are represented by the single-edged combat knives (Bruyako 
Fig. 6. Contextual and cultural distribution. I - distribution of blade weapons of Scythian time in Carpathian-Dniester region ( $\mathrm{a}$ - stray find, $\mathrm{b}$ - flat grave, $\mathrm{c}$ - cremation in flat grave, $\mathrm{d}$ - barrow, e - cremation in a barrow): 1 - Sokirintsy, 2 - Ruski Filvarki (Kamianets-Podilskyi), 3 - Lenkovtsy (Lenkivtsy), 4 - Nelipivtsy, 5 - Lipnic, 6 - Cristinești, 7 - Ibănești, 8 - Cajvana, 9 - Zăicești, 10 - Volodeni, 11 - Rîșcani, 12 - Muncelu de Sus, 13 - Petricani, 14 - Moțca, 15 - Agapia, 16 - Văratec, 17 - Ghindăoani, 18 - Boureni, 19 - Miroslovești, 20 - Mileștii de Sus, 21 - Bârsești, 22 - Buciumeni, 23 - Bălăbănești, 24 - Găiceana, 25 - Nănești, 26 - Lichitișeni, 27 - Suseni, 28 - Mânzătești, 29 - Măcișeni, 30 - Gănești, 31 - Lărguța, 32 - Capaclia, 33 - Vaslui, 34 - Poienești, 35 - Dumești, 36 - Bâcu, 37 - Mircești, 38 - Dănești, 39 - Chircești, 40 - Moșna, 41 - Cozia, 42 - Comarna, 43 - Năvîrneț, 44 - Teșcureni, 45 - Boldurești, 46 - Nisporeni, 47 - Pîrjolteni, 48 - Telenești, 49 - Lucășeuca, 50 - Vatici, 51 - Ivancea, 52 - Trebujeni, 53 - Susleni, 54 - Mikhailovka, 55 - Kotovsk (Podilsk), 56 - Suruceni, 57 - Hansca, 58 - Rezeni, 59 - Butor, 60 - Parcani, 61 - Krasnoe, 62 - Talmaza, 63 - Purcari, 64 - Tudora, 65 - Mayaky, 66 - Nikolaevka (Mikolaivka), 67 - Nikonion (Roksolany), 68 - Gnilyakovo (Dachne), 69 - Diviziya, 70 - Artsyz, 71 - Snake Island (Zmiynyi), 72 - Murighiol, 73 - Enisala, 74 - Celic-dere (Telița), 75 - Chiscani, 76 - Chaush, 77 - Plavni, 78 - Izmail, 79 - Crihana Veche, 80 - Cuhureştii de Jos. II - correlation between burial rite and chronology.

1989, 68). A stray find from Enisala (Simion 1971, fig. 7c) was discovered on the territory of the burial ground, which was generally dated to the $4^{\text {th }}$ century BC (Măndescu 2010, 75). The fragment of the curved dagger from the barrow 1 of Nikonion necropolis was found near the main burial, which was dated back to the second half of the $4^{\text {th }}$ century BC (Bruyako 1989, 68, fig. 1.2). The handle of one of such combat knives was found on the Lower Prut, in the grave 2 of barrow 7 near Crihana Veche (Fig. 5, 5), Cahul District, Republic of Moldova. The bone handle is decorated with silver wire inlay representing a running wave pattern, characteristic of Greek and Thracian production (Ceban et al. 2015, 52, fig. 11). The funeral feast of barrow refers to the middle of the $4^{\text {th }}$ century. BC. All the amphorae (at least 25) found in the ditch and various features can be attributed to the Thasian production. The Thasian amphorae belong to the conical or biconical type of II-B-2 (or advanced biconical) by S. Yu. Monakhov (2003, 60, 67 ), which appears since the late $370 \mathrm{~s}$ BC. There are two-line stamps on five handles, four of which have the name of $\Pi v \lambda \dot{\alpha} \delta \eta \varsigma$ manufacturer. Three imprints are made with one stamp (Bon \& Bon 1957, No. 1504; Garlan 1999, No. 597) and refer to the fifth stage of stamping which dates back to the mid.-350s BC according to Y. Garlan or to the late 360s BC according to V. I. Kats (2007, 415, pril. 2). Another Pylades' stamp contains besides the name of the manufacturer a sign of the eponym: a star (Bon \& Bon 1957, No. 1505; Garlan 1999, No. $633)$ and refers to the same time. The fifth stamp refers to the production of the $\Lambda v \sigma \iota \lambda \hat{\eta} \varsigma$ of 360-50s BC or mid-350s BC according to Y. Garlan (Bon \& Bon 1957, No. 1107; Avram 1996, No. 60; Garlan 1999, No. 593). Thus, the amphoric complex, and, consequently, the time of the burial mound's construction can be attributed to the end of the 360s - the mid.-350s BC (Ceban et al. 2015, 56). 
Early Scythian burials with akinakai between the Carpathians, the Danube and the Dniester, without any exception, are connected with barrows, including the cremations. (Flat graves with early Scythian akinakai are associated exclusively with Transylvania). At the beginning of the Middle Scythian period, flat graves appear, but they, like the burial mounds, are characteristic only of the forest-steppe. The end of the Middle Scythian period is the time of the greatest spread of akinakes and the time of the greatest contextual diversity. Akinakes covers all, without any exception, the regions to the west of the Dniester River, and the "storm of swords" truly becomes a hurricane. The funeral rite also reaches the greatest variety: swords become an integral part of both flat and barrow graves, both cremations and inhumations. At the same time, burial mounds during this period were erected only within the framework of the steppe Danube enclave. By the way, the famous bronze model of akinakes from Medgidia, in my opinion, also refers to this period. Later, in the Classical period, the area of akinakes is significantly reduced: Scythian blade weapons are represented exclusively in the steppe and are represented only by inhumations (although one cremation with akinakes is known in North-Eastern Bulgaria). It is now obvious that weapon preferences are directly related to preferences in the funeral rite and landscape localization (Fig. 6). Thus, these cultural enclaves (the steppe, the Carpathian and the western one) demonstrate uniformity not only in the choice of weapons but also in the funeral rite. The steppe enclave is characterized not only by spearheads and swords but also by the burial mound, while for the western and Carpathian (with their daggers and axes) the flat graves are preferable.

But let's go back to the northeastern Lower Danube region. So, the main weapon of the area is the spear. And according to the panoply contents, the Lower Danube group forms a separate cultural enclave together with the Lower Dniester, South Carpathian and South Danube groups. The panoply influenced affected in a way the morphology of the Scythian akinakes. For instance, the swords are more characteristic than daggers for the steppe Danube region. Daggers are connected mainly with the forest-steppe part of the Carpathian-Dniester region and Transylvania. The most of warrior' assemblages of the Lower Danube region belong mainly to the Classical Scythian period. The only exception is connected with the right bank of the Lower Danube (e.g. early Scythian burial with an akinakes from Celic-Dere). Moreover, in Classical time there are no assemblages with akinakai, but even stray finds outside the steppe. The main element of the funeral rite is the mound and the inhumation (one case of cremation with supposed akinakes in the steppe was recorded to the west, in northeastern Bulgaria, near Branichevo). In late Classical time, from the second half of the $4^{\text {th }}$ century BC, a transformation of the Scythian 
akinakes occurs in the steppe: an original series of single-bladed akinakai of the Chaush type appears and at the same time, the Thracian combat knives are borrowed. Akinakes dissolves with the disappearance of the Classical Scythian culture in the early $3^{\text {rd }}$ century BC. But that happens a century earlier in the forest-steppe between the Dniester and Siret rivers, when the akinakes completely disappears in the late $5^{\text {th }}$ century BC. Then it was excellently linked with the appearance of a huge number of Getian settlements and hillforts in this territory, that corresponds with the data of ancient sources, who placed the Getae to the north of the Danube during this period for the first time. Thus, in the Scythian time, the Lower Danube becomes kind of frontier, or the territory, where "the cultures meet, clash, and grapple with each other, often in contexts of highly asymmetrical relations of power" (Pratt 1991, 34). Or, in other words, it was the territory where the cultural conflict and, as a consequence, cultural dialogue, lead to the cultural exchange. And the Lower Danube panoply of the Scythian period could be considered a special case of this phenomenon.

\section{Acknowledgements}

I would like to express my gratitude to Dr Vitaliy Sinika for the information on unpublished finds of weapons from Budjak steppe, Dr Lavinia Grumeza for the opportunity to present this study in Iași during a workshop about early nomads and Dr Octavian Munteanu for his patience in waiting for the last version of the article.

\section{Bibliography}

Alexandrescu, Alexandrina. 1958. „Două statui traco-scitice din Dobrogea”. SCIV 9, 2: 291-302.

Alexandrescu, Alexandrina. 1960. „În legătura cu statuile scitice.” Studii şi Cercetări de Istorie Veche 11, 2: 383-389.

Andrukh, Svetlana I. 1995. Nizhnedunayskaya Skifiya v VI - nachale I v. do n.e. (etno-politicheskiy aspekt). Zaporozhye: ZGU.

Andrukh, Svetlana I., Andrey O. Dobrolyubskiy and Gennadiy N. Toshchev. 1985. Kurgany u sela Plavni v nizovyakh Dunaya. INION AN SSSR 13.06.1985, №21110. Odessa: OGU im. I. I. Mechnikova.

Aricescu, Andrei. 1965. „Cazanul scitic de la Castelu”. Studii şi Cercetări de Istorie Veche 16, 3: 565-570.

Avram, Alexandru. 1996. Les timbres amphoriques. Thasos. Histria 8. Bucureşti: Editura Enciclopedia. 
Berciu, Dumitru. 1959. „O descoperire traco-scitică din Dobrogea şi problema scitică la Dunărea de Jos”. Studii şi Cercetări de Istorie Veche 1: 7-48.

Bon, Antoine and Anne-Marie Bon. 1957. Les timbres amphoriques de Thasos. Études Thasiennes 4. Paris: École française d'Athènes.

Bruyako, Igor V. 1989. „Predmety vooruzheniya iz Nikoniya“. In Arkheologicheskie pamyatniki stepej Podnestrovya i Podunavya. Kiev: Naukova dumka, $65-70$.

Buzhor, Expectacus. 1958. "O geto-dakiyskoj kulture v Murigiole”. Dacia 2: 125-142.

Ceban, Ion, Denis Topal, Serghei Agulnikov and Sergiu Popovici. 2015. “Tumulul scitic nr. 7 de la Crihana veche La Pietricei (r-nul Cahul)”. Arheologia Preventivă în Republica Moldova 2 (1-2): 43-58.

Chebotarenko, Georgiy F., Evgeniy V. Yarovoy, and Nikolay P. Telnov. 1989. Kurgany budzhakskoy stepi. Kishinev: Shtiintsa.

Dragomir, Ion T. 1983. "Mărturii hallstattiene traco-geto-dacice în regiunea de sud a Moldovei”. Istros II-III, 81-114.

Drevnosti Pridneprovya 1907: Drevnosti Pridneprovya i poberezhya Chyornogo morya. Sobranie B. I. i V. N. Khanenko. 1907. Vypusk 6. Kiev: Fototipiya i tipografiya S. V. Kulzhenko.

Garlan, Yvon. 1999. Les timbres amphoriques de Thasos. Vol. I. Timbres Protothasiens et Thasiens anciens. Études Thasiennes XVIII. Athènes: École française d'Athènes.

Harțuche, Nicolae and Florin Anastasiu. 1976. Catalogul selectiv al colecției de arheologie a Muzeului Brăilei. Brăila: Muzeul Brăilei.

Illinska, Varvara A. 1961. "Skifski sokiri”. Arkheologiya 12: 27-52.

Istoria na Dobrudzha 2011. Todorova, Henrieta, Kiril Yordanov, Velizar Velkov and Sergey Torbatov. Istoria na Dobrudzha. Tom I. Velyko Tarnovo: Faber.

Kats, Vladimir I. 2007. Grecheskie keramicheskie kleyma epokhi klassiki $i$ ellinizma (opyt kompleksnogo izucheniya). Bosporskie issledovaniya 13. Simferopol-Kerch: Demetra.

Măndescu, Dragoș. 2010. Cronologia perioadei timpurii a celei de-a doua Epoci a Fierului (sec. V-III a. Chr.). între Carpați, Nistru şi Balcani. Brăila: Istros.

Matei, Gheorghe and Radu Coman. 2000. „Statuia traco-scitică de la Platoneşti, jud. Ialomița”. Ialomiţa 3: 15-19.

Melyukova, Anna I. 2001. "Novye dannye o skifakh v Dobrudzhe (k voprosu o "Staroy Skifii” Gerodota)”. Rossijskaja Arheologija 4: 20-32.

Monakhov, Sergey Yu. 1999. Grecheskie amfory v Prichernomore. Kompleksy keramicheskoy tary VII-II vekov do n. e. Saratov: Izdatelstvo Saratovskogo universiteta. 
Monakhov, Sergey Yu. 2003. Grecheskie amfory v Prichernomore. Tipologiya amfor vedushchikh tsentrov-eksporterov tovarov $v$ keramicheskoy tare. Katalog-opredelitel. Moskva, Saratov: Kimmerida, Izdatelstvo Saratovskogo universiteta.

Murzin, Vyacheslav Yu. and Vitaliy G. Shlayfer, 2008. "Skifski sokiri-skipetri z Muzeyu istoriï zbroï u m. Zaporizhzhi”. Istoriya zbroï 1: 45-53.

Nikulitse, Ivan T. 1977. Gety IV-III vv. do n. e. v Dnestrovsko-Karpatskikh zemlyakh. Kishinev: Shtiintsa.

Ostroverkhov, Anatoliy S. and Evgeniya F. Redina. 2013. "Skifskie drevnosti”. In Drevnie kultury Severo-Zapadnogo Prichernomorya, edited by Igor V. Bruyako and Tatyana L. Samoylova, 374-418. Odessa: SMIL.

Palamarchuk, Svetlana V. and Vitaliy S. Sinika. 2014. "Skifskie zakhoroneniya iz kurganov v g. Izmail i u s. Kamyshovka”. Stratum plus 3: 291-302.

Pârvan, Vasile. 1926. Getica. O protoistorie a Daciei. Bucureşti: Cultura Naţională.

Patay, Pál. 1990. Die Bronzegefäße in Ungarn. PBF II, 10. München: Beck.

Polin, Sergey V. 2014. Skifskiy Zolotobalkovskiy kurgannyy mogilnik V-IV vv. do n.e. na Khersonshchine. Kurgany Ukrainy 3. Kiev: Oleg Filyuk.

Pratt, Mary Louise. 1991. "Arts of the Contact Zone”. Profession, 33-40.

Redina, Evgeniya F. 1992. „Skifskiy mogilnik Mresnota Mogila“. In Kimmeriytsy $i$ skify. Tezisy dokladov II Mezhdunarodnoy konferentsii, posvyashchennoy pamyati L. I. Terenozhkina, edited by Boris N. Mozolevskiy, 83-84. Melitopol: IA AN Ukrainy.

Redina, Evgeniya F. 1999. "K voprosu o frako-skifskikh kulturnykh vzaimootnosheniyakh (skifskoe odnolezviynoe oruzhie)“. In Problemy skifo-sarmatskoy arkheologii Severnogo Prichernomorya (k 100-letiyu B.N. Grakova), 222_227. Zaporozhe: ZGU.

Simion, Gavrilă. 1992. "Geții şi sciții dinspre gurile Dunării”. Carpica 23 1: 92-105.

Simion, Gavrilă. 1992a. "Geții de la Dunărea de Jos şi civilizația lor”. In Probleme actuale ale istoriei naționale şi universale, edited by Anatol Petrencu, 18-47. Chişinău: Universitas.

Simion, Gavrilă. 2005. "Presences interethniques dans la region des embouchures du Danube aux VI ${ }^{\mathrm{e}}-\mathrm{V}^{\mathrm{e}}$ s. av. J.-C”. In Ethnic contacts and cultural exchanges. North and West of the Black Sea from the Greek colonization to the Ottoman conquest, 43-58. Iaşi: Trinitas

Sinika, Vitaliy S. 2007. "Pogrebalnye pamyatniki skifskoy kultury VII - nachala III v. do n. e. na territorii Dnestro-Prutsko-Dunayskikh stepey". $\mathrm{PhD}$ diss., Moscow State University. 
Sîrbu, Valeriu, Maria-Magdalena Ştefan, Dan Ştefan, Gabriel Jugănaru, and Tomasz Bochnak. 2013. „The necropolis from Telița-Celic Dere $\left(6^{\text {th }}-3^{\text {rd }} c\right.$. BC), Tulcea county, Romania. The study case of tumulus T44". In The Thracians and their neighbours in the Bronze and Iron ages, II, edited by Valeriu Sîrbu, 347-372. Braşov: Istros.

Sîrbu, Valeriu. 1982. "Importuri greceşti în Câmpia Brăilei (sec. V-I î.e.n.)”. Pontica 15: 99-124.

Sîrbu, Valeriu. 2015. "Deux découvertes datant des Ve-IVe s. av. J.-C. à l'est de la Valachie : la tombe de Râmnicelu (dép. de Brăila) et la chaudière d'Ograda (dép. d'Ialomița)”. Thraco-Dacica VI-VII (XXIX-XXX): 51-60.

Skory, Serghey A. and Roman V. Zimovets, 2014. Skifskie drevnosti Kryma. Materialy odnoy kollektsii. Kiev: Oleg Filyuk.

Subbotin, Leonid V., Anatoly S. Ostroverkhov, Sergey B. Okhotnikov and Evgeniya F. Redina. 1992. Skifskie drevnosti Dnestro-Dunayskogo mezhdurechya. Kiev: IA NANU.

Sunichuk, Evgeniya F. 1985. "Skifskiy mogilnik Chaush v nizovyakh Dunaya”. In Pamyatniki drevney istorii Severo-Zapadnogo Prichernomorya, edited by Vladimir P. Vanchugov and Ganna A. Dzis-Rayko, 38-45. Kiev: Naukova dumka.

Sunichuk, Evgeniya F. and Mikhail M. Fokeev. 1984. "Skifskiy mogilnik Plavni I v nizovyakh Dunaya”. In Ranniy zheleznyi vek $v$ Severo-Zapadnom Prichernomorye, edited by Ivan T. Chernyakov, 103-120. Kiev: Naukova dumka.

Teleagă, Emilian 2008. Griechische Importe in den Nekropolen an der unteren Donau 6. Jh. - Anfang des 3. Jhs. v. Chr. Rahden: Marie Leidorf.

Topal, Denis A. 2014. "Finalnaya liniya razvitiya mechey klassicheskoy Skifii. Sootnoshenie tipov Chertomlyk i Shulgovka”. Stratum plus 3: 129-156.

Topal, Denis A. 2018. "Sostav vooruzheniya i vozmozhnosti kulturnoy gruppirovki (na materialakh skifskogo vremeni Karpato-Podunavya)". In Drevnosti, issledovaniya, problemy, edited by Vitaliy S. Sinika and Roman A. Rabinovich, 165-194. Tiraspol: PGU.

Topal, Denis A. 2019. "Scythian akinakai between Carpathians and Dniester: The structure of a storm”. In Un secol de arheologie in spațiul est-carpatic: concepte, metode, tendințe, edited by Vasile Diaconu and Ludmila Pârnău. 141195, Brăila: Istros, Piatra Neamț: Constantin Mătasa.

Torbatov, Sergey. 1998. "Scythian zoomorphic sceptre from North-East Bulgaria”. Arkheologicheski vesti 1: 10-13.

Vulpe, Alexandru 1990. Die Kurzschwerter, Dolche und Streitmesser der Hallstattzeit in Rumänien. PBF VI, 9. München: Beck. 
Yatsenko, Irina V. 1959. "Skifiya VII-V do n. e. (Arkheologicheskie pamyatniki stepnogo Pridneprovya i Priazovya VII-V vv.do n. e.)”. Trudy GIM 6. Moskva: GIM.

\section{Particularitățile panopliei scitice din regiunea Dunării de Jos}

\section{Rezumat}

Peisajul arheologic al Dunării de Jos se schimba odată cu importanța și rolul pe care îl deținea marele fluviu în anumite perioade de timp. Acesta fie se transforma într-o barieră ce despărțea anumite grupuri umane, fie din contra, devenea o arteră care lega diferite comunități antice. În epoca fierului, se pare că Dunărea nu a reprezentat un obstacol de netrecut, inclusiv pentru răspândirea armelor ofensive de origine scitică. Mai mult, Dobrogea acelei perioade arăta ca un teritoriu stăpânit de sciți, începând încă din perioada arhaică. Grupul scitic al Dunării de Jos, împreună cu grupurile Nistrului de Jos, Carpațilo de Sud și Dunării de Sud, formaseră un ansamblu cultural „de stepă”, pentru care lancea devenise principalul tip de armă. Totodată, aceste preferințe s-au reflectat și în morfologia akinakai scitice. Or, pentru această enclavă de stepă sau danubiană, spadele au fost mai utilizate decât pumnalele, acestea din urmă fiind caracteristice mai mult pentru silvostepă regiunii Carpato-Nistrene și Transilvaniei. Mormintele războinice din regiunea Dunării de Jos aparțin mai degrabă perioadei scitice clasice, în timp ce singura excepție este legată de malul drept al Dunării de Jos. Cu toate acestea, în perioada clasică nu există înmormântări cu akinakai în afara stepei și nici chiar descoperiri fortuite. Principala practică funerară este înhumarea cu ridicarea de tumuli, chiar dacă o incineraţie a fost înregistrată în apropiere de Branicevo, în nord-estul Bulgariei. În perioada clasică târzie (350300 a. Chr.), pumnalele scitice evoluează și în stepă, făcându-și apariția o serie originală de akinakai cu un singur tăiș de tip Ceauș, care cunosc o largă circulație de rând cu cuțitele de luptă de origine tracică. La răscrucea secolelor IV-III a. Chr, odată cu prăbușirea culturii clasice scitice, akinakai scitice dispar din circuit. Ceva similar se întâmplase cu un secol mai devreme în silvostepa Sireto-Nistreană. Dispariția completă a akinakai în regiunea respectivă se datează la sfârșitul secolului V a. Chr. Astfel, în perioada scitică, Dunărea de Jos devine un fel de borderland, sau teritoriul, unde „culturile se întâlnesc, se ciocnesc și comunică între ele, deseori în contexte de relații de putere extrem de asimetrice”.

Cuvinte cheie: sciți; epoca timpurie a fierului; Dunărea de Jos; arme; panoplie; akinakai; vârfuri de lance; topoare; săbii; pumnale.

\section{Denis Topal,}

University of High Anthropological School, Chisinau, Republic of Moldova.

E-mail: denis.topal@gmail.com 